\title{
Serum LH concentrations in cyclic buffalo (Bubalus bubalis)
}

\author{
M. L. Kaker, M. N. Razdan and M. M. Galhotra \\ Department of Animal Production Physiology, Haryana Agricultural University, \\ Hissar-125004, India
}

\begin{abstract}
Summary. Circulating LH levels of 14 Murrah buffaloes were determined by a double-antibody radioimmunoassay using an homologous bovine system. At the onset of oestrus, the mean peak circulating LH level was $20.80 \pm 3.43$ (s.e.m.) $\mathrm{ng} / \mathrm{ml}$ in the hotter months (June-August) and $21.24 \pm 0.98 \mathrm{ng} / \mathrm{ml}$ during the cooler months (October-December), values remaining high for about $4 \mathrm{~h}$. Basal levels throughout the rest of the cycle averaged $1-2 \mathrm{ng} / \mathrm{ml}$. Conception occurred in 7 of the animals showing LH peaks (2/8 in June-August, 5/6 in October-December).
\end{abstract}

\section{Introduction}

Luteinizing hormone $(\mathrm{LH})$ has a vital role in various ovarian events and is one factor that influences reproductive cyclicity in female mammals. There have been several reports on circulating LH levels during the oestrous cycle in cattle (Bos taurus) (Henricks, Dickey \& Niswender, 1970; Snook, Saatman \& Hansel, 1971; Madan \& Johnson, 1973; Dobson, 1978) and for the zebu (Bos indicus) (Rao, Rao, Rao, Reddy \& Rao, 1979). Information on LH concentrations in water buffaloes (Bubalus bubalis), however, is scanty (Heranjal, Sheth, Moodbidri, Desai \& Rao, 1976; Sheth, Wadadekar, Moodbidri, Janakiraman \& Parameswardan, 1978). During the hotter months, many buffalo have poor conception rates and exhibit weak symptoms of oestrus (Johari, 1960; Kodagali, 1968; Roy et al., 1968; Roy, Bhattacharya \& Luktuke, 1972) and this reduced fertility is of economic importance because the buffalo contributes greatly towards milk and meat production in many countries. We have therefore examined circulating $\mathrm{LH}$ concentrations in buffaloes at various stages of the oestrous cycle during hotter and cooler months.

\section{Materials and Methods}

\section{Animals}

The 14 animals were Murrah buffaloes (Bubalus bubalis). They had a known breeding history and had been cycling regularly (20-22 days) before being taken at random from the University Farm. A young vasectomized buffalo bull was taken to the experimental animals three times a day $(05: 00,13: 00$ and $21: 00 \mathrm{~h})$ for detection of oestrus. An animal detected in oestrus was isolated immediately. In addition, the animals were kept under constant surveillance. Eight of these animals (Group 1) were detected in oestrus in the hotter months of June to August $\left(32 \cdot 5-40 \cdot 3{ }^{\circ} \mathrm{C}\right.$ mean maximum ambient temperature); the rest (Group 2) came into oestrus in the cooler months of October to December $\left(23 \cdot 2-34 \cdot 5^{\circ} \mathrm{C}\right)$. The animals in oestrus were rectally palpated once to confirm follicular growth in the ovaries, and smears of the vaginal mucus were examined for the fern patterns associated with oestrus. At this oestrus the females were mated by a bull of proven fertility. 
Blood samples were collected when oestrus was first detected and then every $4 \mathrm{~h}$ for $24 \mathrm{~h}$, followed by sampling on every $3 \mathrm{rd}$ day for a further period of 26 days. Serum was separated at $5^{\circ} \mathrm{C}$ and stored frozen until used for assay of $\mathrm{LH}$.

\section{LH assay}

Method. The double-antibody radioimmunoassay system of Niswender, Reichert, Midgley \& Nalbandov (1969) was used, with slight modifications, to measure LH concentrations. An homologous complete bovine system formed the basis of the assay. Purified bovine LH (LER-1072-2) was radioiodinated with ${ }^{125} \mathrm{I}$ at room temperature $\left(28^{\circ} \mathrm{C}\right)$ by a modification of the method of Greenwood, Hunter \& Glover (1963): $2.5 \mu \mathrm{g}$ bLH were reacted for $1 \mathrm{~min}$ with $1 \mathrm{mCi}$ sodium ${ }^{125} \mathrm{I}$ in the presence of $50 \mu \mathrm{g}$ chloramine $\mathrm{T}$. The reaction was stopped by adding $125 \mu \mathrm{g}$ sodium metabisulphite. This was followed by purification of the labelled bLH by passing it through a Sephadex G-50 column $(0.8 \times 20 \mathrm{~cm})$. The labelled bLH stock solution was repurified every time before use. The antiserum to bLH (B-225) was raised, characterized and purified for monospecificity by Dr G. D. Niswender, Colorado State University, U.S.A., and its titre was determined before use.

A standard preparation of bLH (NIH-LH-B 10) was diluted with $0.1 \%$ egg white- 0.01 M-phosphate buffer-0.14 M-NaCl, $\mathrm{pH} 7.0$ (EW-PBS) to obtain different standard doses, i.e. $0.125,0.25,0.5,1.0,2.0$ and $4.0 \mathrm{ng}$ in $500 \mu \mathrm{l}$, for the dose-response curve. Different standards and various amounts of serum $(50-300 \mu \mathrm{l})$ were placed in the assay tubes $(10 \times 75 \mathrm{~mm})$, and $0.1 \% \mathrm{EW}-\mathrm{PBS}$ was added to bring the volume to $500 \mu \mathrm{l}$ in each tube. The non-immune normal rabbit serum (NRS) was diluted $1: 400$ in $0.05 \mathrm{M}$-EDTA-PBS at $\mathrm{pH} 7.0$. This diluted serum was used for the dilution of anti-bLH serum (1:80 000). To each of the assay tubes $200 \mu \mathrm{l}$ diluted anti-bLH serum were added, and the contents were mixed and incubated for $24 \mathrm{~h}$ at $4{ }^{\circ} \mathrm{C} ; 100 \mu \mathrm{l}$ labelled bLH (approximately 10000 c.p.m.) were added before incubation for a further $24 \mathrm{~h}$. Then $200 \mu l$ anti-rabbit gammaglobulin, diluted 1:12, were added to each tube which was kept for $48 \mathrm{~h}$ to precipitate the bound fraction. All the tubes were counted for total activity using a manual Gamma Spectrometer (ECIL, GRS-23 A). After addition of $2.5 \mathrm{ml}$ cold PBS to each tube, the contents of each tube were centrifuged at $1000 \mathrm{~g}$ and $5^{\circ} \mathrm{C}$ for $30 \mathrm{~min}$. The supernatant was carefully decanted and the precipitate was counted for activity in the bound fraction. Percentage binding was calculated for each tube. The standard dose-response curve was prepared by plotting standard doses and percentage binding on logit-log paper. The slope of the curve was determined by linear regression analysis. The correlation coefficient was also calculated. The concentration of $\mathrm{LH}$ in the serum samples was determined from the standard

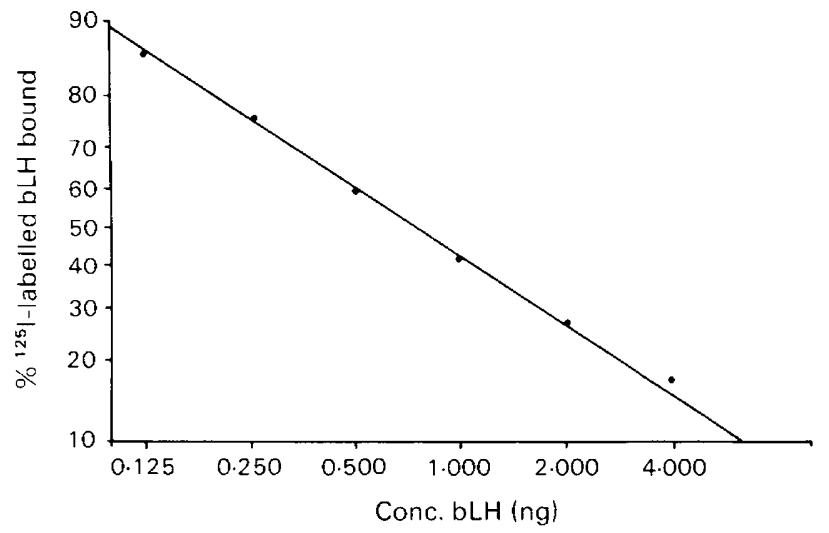

Text-fig. 1. Logit-log transformation of a representative dose-response curve for the assay of bovine $\mathrm{LH}$ in buffalo serum. 
curve. The tubes containing the standards and the serum samples were run in duplicate and the average of the two taken for calculation. A set of standard doses was run and a standard curve was prepared for each assay of the serum samples.

Validation. The anti-bLH serum used bound approximately $30 \%$ of ${ }^{125} \mathrm{I}$-labelled bLH at a dilution of 1:80 000 in the absence of bLH standard or unknown serum. This initial binding was considered to represent $100 \%$ for calculation of percentage binding in the tubes containing the standards and serum samples. A representative dose-response curve is shown in Text-fig. 1. The slope of the standard curve was found to be -2.32 and the correlation coefficient was 0.99 . Non-specific binding ranged between 2.5 and $5 \%$ in different assays. The quantity of the serum did not affect the LH estimate when tested in volumes varying from 100 to $300 \mu$ for each assay tube. The sensitivity of the assay was up to a minumum hormone level of $0.125 \mathrm{ng}$. The intra-assay variation was within $5 \%$ and inter-assay variation was $8.62 \%$ for 7 assays.

\section{Results}

\section{Group 1}

Rectal palpation of the oestrous animals revealed the presence of a small Graafian follicle and the vaginal mucus smear exhibited a typical fern pattern.

Individual $\mathrm{LH}$ values during the first $24 \mathrm{~h}$ after the detection of oestrus are given in Table 1 and those on different days after oestrus are shown in Table 2. Buffaloes 1, 2 and 3 had the highest concentrations at the time of detection of oestrus. Buffaloes 4 and 5 showed peak levels at 20 and $24 \mathrm{~h}$. Buffaloes 6 and 7 did not exhibit elevated LH levels within the first $24 \mathrm{~h}$ after

Table 1. Serum $\mathrm{LH}$ levels $(\mathrm{ng} / \mathrm{ml})$ at different times after detection of oestrus in Murrah buffaloes during the hotter months of June-August

\begin{tabular}{|c|c|c|c|c|c|c|c|c|}
\hline \multirow{2}{*}{$\begin{array}{l}\text { Time after } \\
\text { detection of } \\
\text { oestrus (h) }\end{array}$} & \multicolumn{8}{|c|}{ Buffalo no. } \\
\hline & 1 & 2 & 3 & 4 & 5 & 6 & 7 & 8 \\
\hline 0 & 22.00 & 32.00 & $12 \cdot 25$ & 1.60 & $4 \cdot 15$ & 2.42 & 3.80 & $2 \cdot 84$ \\
\hline 4 & 13.00 & 2.45 & $4 \cdot 70$ & 1.90 & 3.40 & $2 \cdot 10$ & 2.75 & 5.75 \\
\hline 8 & 2.65 & 1.40 & 1.38 & 1.60 & 2.25 & 1.60 & 1.25 & 21.90 \\
\hline 12 & 2.43 & 0.85 & 1.47 & 5.44 & 2.03 & 1.48 & 1.70 & 3.79 \\
\hline 16 & $2 \cdot 86$ & 1.27 & $1 \cdot 13$ & - & $2 \cdot 56$ & 1.78 & 0.96 & $4 \cdot 16$ \\
\hline 20 & 1.63 & 1.83 & 1.13 & $15 \cdot 15$ & $2 \cdot 13$ & 1.86 & 1.33 & 1.69 \\
\hline 24 & $2 \cdot 30$ & 0.97 & 0.98 & 6.99 & $22 \cdot 64$ & 2.06 & $2 \cdot 17$ & 1.63 \\
\hline
\end{tabular}

Table 2. Serum LH levels ( $\mathrm{ng} / \mathrm{ml}$ ) on different days of the oestrous cycle of Murrah buffaloes during the hotter months of June-August

\begin{tabular}{|c|c|c|c|c|c|c|c|c|c|}
\hline \multirow{2}{*}{$\begin{array}{l}\text { Time after } \\
\text { detection } \\
\text { of oestrus } \\
\text { (days) }\end{array}$} & \multicolumn{5}{|c|}{ Buffalo no. } & \multirow{2}{*}{$\begin{array}{c}\text { Mean } \pm \text { s.e.m. } \\
\text { for Buffaloes } \\
1-5\end{array}$} & \multicolumn{3}{|c|}{ Buffalo no. } \\
\hline & 1 & 2 & 3 & 4 & 5 & & 6 & 7 & 8 \\
\hline 1 & 22.00 & 32.00 & $12 \cdot 25$ & $15 \cdot 15$ & $22 \cdot 64$ & $20.80 \pm 3.43$ & 2.06 & $3 \cdot 80$ & 21.90 \\
\hline 2 & $1 \cdot 10$ & $1 \cdot 30$ & 1.08 & 1.38 & 1.26 & $1.21 \pm 0.23$ & 0.90 & $1 \cdot 33$ & 1.66 \\
\hline 5 & 0.93 & 0.64 & 1.03 & 1.20 & 1.96 & $1.15 \pm 0.22$ & 1.08 & 0.92 & - \\
\hline 8 & 0.85 & 0.64 & 0.75 & 1.20 & 1.38 & $0.96 \pm 0.14$ & 3.23 & 1.33 & $2 \cdot 19$ \\
\hline 11 & 3.50 & 0.92 & 0.73 & 0.78 & $1 \cdot 36$ & $1.46 \pm 0.52$ & 0.85 & $3 \cdot 16$ & $12 \cdot 39$ \\
\hline 14 & 0.70 & 0.61 & 0.98 & 1.96 & 1.66 & $1.18 \pm 0.27$ & 0.85 & 0.82 & $2 \cdot 88$ \\
\hline 17 & 2.63 & 1.63 & 1.33 & 1.80 & 0.98 & $1.67 \pm 0.28$ & 0.70 & $2 \cdot 70$ & 1.91 \\
\hline 20 & 1.71 & $2 \cdot 31$ & 0.83 & 0.70 & $1 \cdot 38$ & $1.39 \pm 0.29$ & 0.92 & - & 1.86 \\
\hline 23 & 0.88 & 4.90 & 1.03 & 0.78 & $1 \cdot 16$ & $1.75 \pm 0.79$ & 1.08 & - & 1.75 \\
\hline 26 & 0.95 & - & - & 0.60 & 0.62 & $0.72 \pm 0.11$ & 0.90 & - & - \\
\hline
\end{tabular}


detection of oestrus or on subsequent days. Buffalo 8 showed an LH peak at $8 \mathrm{~h}$ and another peak on Day 11, but values on other days were basal. Non-peak values in the 8 animals ranged from 0.60 to $13.00 \mathrm{ng} / \mathrm{ml}$, although values at $4 \mathrm{~h}$ after the peak value were generally higher than those on other days. Buffaloes 3 and 4 conceived but none of the others did so.

\section{Group 2}

Graafian follicles were detected by rectal palpation but they were generally larger than those in Group 1 animals. The vaginal mucus dried in a fern pattern as in the summer months.

The LH concentrations in Buffaloes 9-14 are given in Tables 3 and 4. Buffaloes 9-12 showed peak LH levels at 0 or $4 \mathrm{~h}$ after detection of oestrus, but there was no detectable peak in Buffaloes 13 and 14 in the first $24 \mathrm{~h}$. However, both animals had their highest concentrations on Day 2, although only that for Buffalo 13 was within the range shown by Buffaloes 9-12. Concentrations were again higher at $4 \mathrm{~h}$ after the peak value, while values on other days ranged from 0.37 to $4.99 \mathrm{ng} / \mathrm{ml}$. Buffaloes 9-13 conceived but Buffalo 14 did not.

Table 3. Serum LH levels $(\mathrm{ng} / \mathrm{ml})$ at different times after detection of oestrus in Murrah buffaloes during the cooler months of October-December

\begin{tabular}{crrrrrr}
\hline $\begin{array}{c}\text { Time after } \\
\text { detection } \\
\text { of oestrus } \\
\text { (h) }\end{array}$ & \multicolumn{7}{c}{ Buffalo no. } \\
\cline { 2 - 7 } & 9 & 10 & 11 & 12 & 13 & 14 \\
\hline 0 & 21.25 & 22.22 & 23.00 & 4.77 & 1.00 & 1.45 \\
4 & 3.75 & 9.00 & 9.90 & 18.50 & 0.98 & 1.51 \\
8 & 0.97 & 2.60 & 1.73 & 4.90 & 2.13 & 1.88 \\
12 & 0.85 & 1.83 & 1.16 & 1.76 & 2.06 & 0.97 \\
16 & 0.90 & 0.88 & 1.21 & 1.56 & 3.03 & 1.20 \\
20 & 0.61 & 0.57 & 1.16 & 2.23 & 2.36 & 0.90 \\
24 & 0.59 & 3.75 & 0.53 & 1.35 & 1.23 & 0.81 \\
\hline
\end{tabular}

Table 4. Serum LH levels $(\mathrm{ng} / \mathrm{ml})$ on different days of the oestrous cycle in Murrah buffaloes during the cooler months of October-December

\begin{tabular}{|c|c|c|c|c|c|c|c|}
\hline \multirow{2}{*}{$\begin{array}{l}\text { Time after } \\
\text { detection } \\
\text { of oestrus } \\
\text { (days) }\end{array}$} & \multicolumn{4}{|c|}{ Buffalo no. } & \multirow{2}{*}{$\begin{array}{l}\text { Mean } \pm \text { s.e.m. } \\
\text { for Buffaloes } \\
\quad 9-12\end{array}$} & \multicolumn{2}{|c|}{ Buffalo no. } \\
\hline & 9 & 10 & 11 & 12 & & 13 & 14 \\
\hline 1 & $21 \cdot 25$ & $22 \cdot 22$ & 23.00 & $18 \cdot 50$ & $21.24 \pm 0.98$ & 3.03 & 1.88 \\
\hline 2 & 0.96 & 0.71 & 0.68 & $1 \cdot 18$ & $0.88 \pm 0.12$ & 21.00 & 3.87 \\
\hline 5 & 1.29 & 1.83 & 0.66 & 0.58 & $1.09 \pm 0.29$ & 0.73 & 0.81 \\
\hline 8 & 0.62 & 0.93 & $1 \cdot 11$ & 0.96 & $0.90 \pm 0.10$ & 2.25 & 0.79 \\
\hline 11 & 0.80 & 1.26 & 0.42 & 1.05 & $0.88 \pm 0.18$ & 0.65 & 0.57 \\
\hline 14 & 0.90 & 0.80 & 0.57 & 1.70 & $0.99 \pm 0.24$ & 0.96 & 0.62 \\
\hline 17 & 0.95 & 0.85 & 0.48 & 1.40 & $0.92 \pm 0.19$ & - & 0.61 \\
\hline 20 & 1.25 & 0.53 & 0.62 & 4.99 & $1.85 \pm 1.06$ & 0.65 & 0.59 \\
\hline 23 & $1 \cdot 12$ & 0.68 & 0.37 & - & $0.72 \pm 0.22$ & 1.63 & 0.45 \\
\hline 26 & 0.69 & 0.85 & 0.67 & - & $0.74 \pm 0.06$ & 1.51 & 1.01 \\
\hline
\end{tabular}

\section{Discussion}

The higher $\mathbf{L H}$ concentrations in most of the buffaloes at the time they were detected in oestrus are consistent with observations on cattle (Henricks et al., 1970; Madan \& Johnson, 1973; Schams, Schallenberger, Hoffman \& Karg, 1977; Dobson, 1978). However, large variations in the peak LH levels of cattle have been reported by different workers. The mean peak LH levels 
in buffaloes obtained in our study (about $21 \mathrm{ng} / \mathrm{ml}$ in both groups) are comparable to the reports of Webb, Lamming, Haynes, Hafs \& Manns (1977), Schams et al. $(1977,1978)$ and Dobson (1978) but are lower than those reported by Niswender et al. (1969), Henricks et al. (1970), Madan \& Johnson (1973), Kaltenbach et al. (1974) and Lemon, Pelletier, Saumande \& Signoret (1975). Our values are also lower than those obtained by Rao et al. (1979) for 2 zebu cows $(57.5 \mathrm{ng} / \mathrm{ml})$. In our study, the mean basal LH levels was about $1.28 \mathrm{ng} / \mathrm{ml}$ in Buffaloes $1-5$ in the hotter months and about $1 \mathrm{ng} / \mathrm{ml}$ in Buffaloes 9-12 during the cooler months. These values are comparable to the basal values reported for cattle. Heranjal et al. (1976) measured circulating $\mathrm{LH}$ levels of 7 Murrah buffaloes during the oestrous cycle and reported peak levels of $14.03-38.5 \mathrm{ng} / \mathrm{ml}$ at oestrus and basal levels between 5.4 and $9.8 \mathrm{ng} / \mathrm{ml}$ at other times during the cycle. These values are higher than those found in the present study, but we cannot explain them unless it be due to the different assay systems employed. The report of Sheth et al. (1978) shows mean circulating LH levels of $19.8 \mathrm{ng} / \mathrm{ml}$ at oestrus and $14.8 \mathrm{ng} / \mathrm{ml}$ on Day 15 of the cycle in buffaloes of the Surti breed during winter. This high Day 15 value is hard to explain by breed or assay differences.

Conception rate was better in Group $2(5 / 6)$ than in Group $1(2 / 8)$ animals. Of the animals that did not conceive 4 (Nos 1, 2, 5 and 8) had what appeared to be good (in value and timing) LH peaks, and a failure of ovulation seems unlikely. An LH peak was not observed in Buffaloes 6, 7 and 13; it is possible that this was missed during the sampling schedule but none of the 3 animals conceived and they may not therefore have ovulated.

Only one animal (No. 8) showed a small mid-cycle LH peak followed by a fall to basal LH levels. The appearance of a mid-cycle LH peak in buffaloes was reported by Heranjal et al. (1976) and has also been found in cattle (Snook et al., 1971): it is thought to be correlated with growth and atresia of anovulatory follicles.

Although there was a difference in conception rate for the buffaloes coming into oestrus in the hotter and cooler months, there was no appreciable difference in the mean peak or basal levels of LH. However, these observations are based on only small numbers of animals and generalizations are unwarranted.

This work was carried out under a research project sponsored by the Indian Council of Agricultural Research, New Delhi. We thank NIAMDD, Bethesda, U.S.A., for the generous gift of standard bovine LH; Dr G. D. Niswender for antiserum to bovine LH; Dr L. E. Reichert for highly purified bovine LH; the Department of Livestock Production and Management of the Haryana Agricultural University for the animals; and Dr M. L. Madan, now at NDRI, Karnal, for help during the initial stages of the project.

\section{References}

Dobson, H. (1978) Plasma gonadotrophins and oestradiol during oestrus in the cow. J. Reprod. Fert. 52, 51-53.

Greenwood, F.C., Hunter, W.M. \& Glover, J.S. (1963) The preparation of ${ }^{131}$ I-labelled human growth hormone of high specific activity. Biochem. J. 89, 114-123.

Henricks, D.M., Dickey, J.F. \& Niswender, G.D. (1970) Serum luteinizing hormone and plasma progesterone levels during the estrous cycle and early pregnancy in cows. Biol. Reprod. 2, 346-351.

Heranjal, D.D., Sheth, A.R., Moodbidri, S.B., Desai, R. \& Rao, S.S. (1976) A note on LH during estrous cycle and early pregnancy in Indian buffaloes. Indian J. Anim. Sci. 46, 553-555.
Johari, M.P. (1960) Studies on the sexual physiology of water buffaloes. Indian vet. J. 37, 354-364.

Kaltenbach, C.C., Dunn, T.G., Kiser, T.E., Corah, L.R., Akbar, A.M. \& Niswender, G.D. (1974) Release of FSH and LH in beef heifers by synthetic gonadotrophin releasing hormone. J. Anim. Sci. 38, $357-362$.

Kodagali, S.B. (1968) A note on reproductive disorder of farm animals in Saurastra. Indian J. vet. Sci. 38, 286-287.

Lemon, M., Pelletier, J., Saumande, J. \& Signoret, J.P. (1975) Peripheral plasma concentrations of progesterone, oestradiol-17 $\beta$, and luteinizing hormone around oestrus in the cow. J. Reprod. Fert. 42, $137-140$.

Downloaded from Bioscientifica.com at 04/26/2023 10:42:30AM via free access 
Madan, M.L. \& Johnson, H.D. (1973) Environmental heat effects on bovine luteinizing hormone. J. Dairy Sci. 56, 1420-1423.

Niswender, G.D., Reichert, L.E., Jr, Midgley, A.R., Jr \& Nalbandov, A.V. (1969) Radioimmunoassay for bovine and ovine luteinizing hormone. Endocrinology 84, 1166-1173.

Rao, K.B., Rao, P.N., Rao, K.S., Reddy, K.K. \& Rao, N.J. (1979) Serum luteinizing hormone levels in normally and abnormally cycling Ongole cows. Indian vet. J. 56, 189-198.

Roy, A., Raizada, B.C., Tiwari, R.B.L., Pandey, M.D., Yadva, P.C. \& Sengupta, B.P. (1968) Effect of management on the fertility of buffalo cows bred during summer. Indian J. Dairy Sci. 38, 554-560.

Roy, D.J., Bhattacharya, A.R. \& Luktuke, S.N. (1972) Oestrus and ovarian activities of buffaloes in different months. Indian vet. J. 49, 54-60.

Schams, D., Schallenberger, E., Hoffmann, B. \& Karg, H. (1977) Hormonal parameters and time relationship concerning oestrus, ovulation and electrical resist- ance of the vaginal mucus. Acta endocr., Copenh. 86, $180-192$.

Schams, D., Schallenberger, E., Menzer, C., Stangl, J., Zottmeier, K., Hoffmann, B. \& Karg, H. (1978) Profiles of luteinizing hormone, follicle stimulating hormone and progesterone in post partum dairy cows and their relationship to the commencement of cyclic functions. Theriogenology 10, 453-468.

Sheth, A.R., Wadadekar, K.B., Moodbidri, S.B., Janakiraman, J. \& Parameswardan, M. (1978) Seasonal alteration in the serum prolactin and $\mathbf{L H}$ levels in the water buffaloes. Curr. Sci. 47, 75-77.

Snook, R.B., Saatman, R.R., \& Hansel, W. (1971) Serum progesterone and luteinizing hormone levels during the bovine estrous cycle. Endocrinology 88, 678-686.

Webb, R., Lamming, G.E., Haynes, N.B., Hafs, H.D. \& Manns, J.G. (1977) Response of cyclic and postpartum suckled cows to injections of synthetic LH-RH. J. Reprod. Fert. 50, 203-210.

Received 19 March 1980 